\title{
Elections and Civil War in Africa*
}

\author{
JOSÉ A. CHEIBUB AND JUDE C. HAYS
}

$T$ he view that multiparty elections in changing authoritarian regimes should be held sooner rather than later has been increasingly under attack. Critics argue that, under conditions of low institutional development, multiparty elections may lead to violence and civil war, rather than to the peaceful allocation of authority that everyone desires. Starting from the premise that elections are strategically timed and endogenous in transitioning authoritarian regimes, that is, more likely to be held when violence is imminent, we show that for Africa, the continent with the lowest levels of political institutionalization, elections do not increase the probability of a civil war initiation. In fact, for the post-Cold War period, the holding of multiparty elections is actually associated with a substantial reduction in the probability of civil war onset. To account for this pattern, we develop an informational theory of elections held under conditions that prevail in the post-Cold War, when foreign powers are reluctant to provide direct support for dictators (or their opponents) and elections are more reflective of the true level of a leader's strength. We argue that, under these conditions, elections may prevent the eruption of a civil war that is already imminent, through two mechanisms: they may deter a weak opposition from initiating a war they are likely to lose or they may induce a weak dictator to offer ways to share power with the opposition.

$\mathrm{D}$ o elections in authoritarian regimes cause civil war? The answer to this question has generated a lively debate among both academics and policy analysts. According to one side of this debate, elections are the fundamental element and the most important event in any democratic regime and should be the immediate goal in any attempt to establish democracy. This is the default position, which, as such, had not been articulated explicitly until it was challenged. It stems from the combination of two lines of research, regime transitions and the "democratic peace," and is expressed in the policies of the international community, most notably of the United States and its democracy promotion agencies. ${ }^{1}$

The other side in the debate argues that elections, if held too early as authoritarian regimes change, can have catastrophic consequences. Prompted by the eruption or intensification of

* José A. Cheibub is a Professor in the Department of Political Science, University of Illinois at Urbana-Champaign, 420 David Kinley Hall, Gregory Drive, Urbana, IL 61801 (cheibub@illinois.edu). Jude C. Hays is an Associate Professor in the Department of Political Science, University of Pittsburgh, 4600 Wesley W. Posvar Hall, Pittsburgh, PA 15260 (jch61@pitt.edu). José A. Cheibub acknowledges the Research Council of Norway (FRISAM 222442) for support during this research. For comments on earlier drafts, the authors thank participants in presentations at the University of Illinois, University of Minnesota, University of Oslo, University of Pittsburgh, Princeton University, University of Virginia, University of Washington in St. Louis, Yale University, and the annual meetings of the Midwest Political Science Association 2012, Eurasian Peace Science 2012, Peace Science Society 2011, European Political Science Association 2011, International Studies Association 2011, and the American Political Science Association 2010. The authors also thank Stephen Chaudoin, Scott Cook, Xiniuan Dai, Paul Diehl, Nicholas Sambanis, Burcu Savun, Alastair Smith, and Milan Svolik for their insights and help with earlier versions of this paper. To view supplementary material for this article, please visit http://dx.doi.org/10.1017/psrm.2015.33

1 Work on regime transition emphasized the role of competitive elections in marking the beginning of democracy; work on the democratic peace noted that democracies do not fight each other and, consequently, a world populated with democratic regimes would be a peaceful one. See Hyde (2011) for evidence about the international community's commitment to multiparty elections in developing countries. 
large-scale conflicts around national elections in the Balkans and in many African countries in the early 1990s, many observers have come to believe that, because they may provoke war, elections may hinder rather than foster the process of democratization. Consequently, although necessary for democracy to exist, elections, according to this view, should not necessarily be the immediate or tactical goal in the process of democratization. When they are held in a context in which conflict is ripe and existing institutions are weak, the opportunities for violence are overwhelming. ${ }^{2}$

In this article, we provide an alternative way to view the relationship between elections and civil conflict in weakly institutionalized regimes. We argue that in these contexts leaders choose to hold elections strategically to stave off violence. We propose a theory in which multiparty elections reduce the likelihood of civil war onset by providing information about the leader's level of internal political support. Under the right conditions, this information deters weak opponents from initiating conflict and facilitates power sharing when the opposition is strong. As leaders in transitioning regimes are more likely to hold elections when the probability of civil war is high, the pacifying effects of these contests are not easily identified. We test this theory on data for Africa and find support for the argument during the post-Cold War period.

\section{WHY WOULD MULTIPARTY ELECTIONS LEAD TO CIVIL WAR?}

Although the number of civil wars has not increased in the past decade, the level of violence associated with democratization is perceived as having increased (e.g., Collier 2009). Prompted by this observation, several analysts have articulated a critical perspective regarding democratization. According to this perspective, under conditions of low institutional capacity, political liberalization or pressures for democratization are counterproductive: they generate conflict rather than peaceful democratization. In the absence of strong institutions, not all individual steps in the direction of democracy in transitional countries necessarily lead to the desired outcome. This perspective, rooted in Huntington's (1968) argument about the importance of institutionalization and the dangers of praetorianism stemming from political mobilization without strong institutions, has become widespread (e.g., Snyder 2000; Chua 2003; Collier 2009 among many others).

One important theoretical strand of the argument is associated with the notion of "anocracy." These regimes are considered to be incoherent, in the sense that they are neither full-blown dictatorships nor full-blown democracies. Had they been the former, presumably they would have been willing and capable of employing coercion to resolve existing conflicts; had they been the latter, conflicts would have been processed through institutionalized channels such as political parties, legislatures, and courts. In neither case would these conflicts escalate into civil wars. Civil war in this view is the product of being in a transitional state in which repression "cannot" be fully applied, but conflicts "cannot" be fully processed through democratic institutions (Hegre et al. 2001).

Snyder $(2000,39)$, in turn, proposes that the outcome of a process of liberalization of an authoritarian regime depends on two factors: the adaptability of the authoritarian elites to a post-liberalization environment and the strength of a country's political institutions. When elites fear that they may lose under democratic rules and institutions are weak, a situation that,

\footnotetext{
${ }^{2}$ See Snyder (2000) and Zakaria (1997). Some scholars argue that this is especially true in post-conflict situations. The literature that developed around post-war elections, however, is not theoretically distinct from the literature on early elections in transitioning regimes. The theoretical argument is the same, although the scope conditions are narrower.
} 
according to him, characterizes most contemporary authoritarian regimes, political liberalization is most likely to lead to ethnic and other types of civil conflicts.

The bulk of the existing evidence seems to support this view. Snyder (2000) provides a series of case studies that link political liberalization (including elections) to the eruption of civil wars, and several recent papers, analyzing cross-national data sets, claim to establish the causal impact of democratization and elections on civil conflict initiation (Hegre et al. 2001; Cederman, Hug and Krebs 2010; Cederman, Gleditsch and Hug 2012; Flores and Nooruddin 2012; Snyder and Mansfield 2012; Brancati and Snyder 2013). The research on multiparty elections shows that the connection to violence in weakly institutionalized settings depends on a couple of factors. First, the level and type of violence are important. Post-electoral violence can be spontaneous and disorganized in its nature or result from fighting between states and organized rebel groups with well-defined political objectives. The level of violence seems to matter as well. Civil conflicts, for instance, are typically separated into civil wars, conflicts that surpass a high battledeaths threshold, and minor conflicts that produce far fewer fatalities. Second, the degree of electoral competition, which varies depending on the political strength of the opposition, has been shown to condition the effect of multiparty elections on civil and social conflict.

More specifically, Cederman, Gleditsch and Hug (2012) analyze a global sample from 1960 to 2000 and find that competitive elections, particularly first and second elections, increase the likelihood of ethnic civil conflicts. Their analysis includes both minor conflicts that followed competitive elections (e.g., Niger and Chad in the mid-1990s) as well as major civil wars (e.g., Congo in 1993). Salehyan and Linebarger (2015) show that elections are associated with an increase in spontaneous disorganized social violence in Africa during the post-Cold War period and that the relationship is stronger for competitive elections. Flores and Nooruddin (2012) and Brancati and Snyder (2013) find that early elections in post-conflict settings - that is, cases in which the opposition is relatively strong and institutions are weak-increase the likelihood of conflict and civil war recurrence, respectively.

These are important claims, which, in addition to being intrinsically interesting, have far-reaching implications for democracy promotion. They underscore the possibility that pressure by international actors to implement democratic reforms, often revolving around elections, may be counterproductive; however, is the connection between elections and violence constant across time, levels of electoral competition, and types of conflict?

In Table 1, we present some evidence on the relationship between civil conflict onset and multiparty elections in Africa from 1946 to 2005. By focusing on Africa, we restrict the sample to cases where institutional capacity is relatively low on average (Bratton and van de Walle 1997; Kuenzi and Lambright 2001; Ndulo 2007), although we recognize that there is important variation across the continent. ${ }^{3}$ Africa also experienced a disproportionately high number of civil wars over the sample period relative to other regions of the world. We distinguish between civil wars and minor civil conflicts, as well as competitive and non-competitive multiparty elections by the distribution of vote shares. We also look at these relationships for the Cold War and post-Cold War periods.

Our elections data set is composed of all African countries since 1946 (the number of independent countries in Africa increased from four in 1946 to 53 in 2005). Between 1946 and 2005, there were 639 electoral contests in Africa: 266 presidential, 359 for legislative lower houses, and 14 for legislative upper houses. Of these, 345 were multiparty elections, defined as elections in which no party got 100 percent of the vote: 144 were presidential and 201 for the

\footnotetext{
${ }^{3}$ Posner and Young (2007), for example, argue that institutionalization in Africa, although historically low, has been increasing since the 1990s. We discuss this and related issues in more detail below.
} 
TA B LE $1 \quad$ Multiparty Elections and the Relative Frequency of Civil Conflict Onset in Africa

\begin{tabular}{|c|c|c|c|c|c|c|}
\hline \multirow[b]{2}{*}{ Multiparty Election } & \multicolumn{3}{|c|}{ Civil War } & \multicolumn{3}{|c|}{ Minor Conflict } \\
\hline & $100 \%$ & $90 \%$ & $50 \%$ & $100 \%$ & $90 \%$ & $50 \%$ \\
\hline \multicolumn{7}{|c|}{ Post-WWII (1946-2005) } \\
\hline No & 2.82 & 2.74 & 2.54 & 3.72 & 3.68 & 3.56 \\
\hline Yes & 2.39 & 2.54 & 3.61 & 4.12 & 4.30 & 5.49 \\
\hline$\chi^{2}$ & 0.35 & 0.06 & 1.15 & 0.23 & 0.50 & $3.11^{*}$ \\
\hline \multicolumn{7}{|c|}{ Cold War (1946-1989) } \\
\hline No & 1.83 & 1.88 & 1.94 & 3.01 & 2.98 & 2.93 \\
\hline Yes & 3.42 & 3.74 & 5.26 & 3.73 & 4.15 & 6.12 \\
\hline$\chi^{2}$ & $2.77 *$ & $2.95 *$ & $4.62 * *$ & 0.40 & 0.82 & $3.03^{*}$ \\
\hline \multicolumn{7}{|c|}{ Post-Cold War (1990-2005) } \\
\hline No & 5.58 & 5.03 & 3.81 & 5.43 & 5.30 & 4.71 \\
\hline Yes & 1.67 & 1.86 & 2.86 & 4.35 & 4.38 & 5.26 \\
\hline$\chi^{2}$ & $9.04 * * *$ & $5.91 * *$ & 0.41 & 0.62 & $\begin{array}{l}4.50 \\
0.45\end{array}$ & 0.13 \\
\hline
\end{tabular}

Notes: the $\chi^{2}$ statistics, calculated from the full $2 \times 2$ contingency tables, test the null hypothesis that the timing of multiparty elections and civil conflict onsets are independent. ***Significant at the .01 level, **Significant at the .05 level, and *Significant at the .10 Level.

lower house. If we use a stricter definition of multiparty elections, one requiring that no party garner more than 90 percent of the vote, the total number drops to 284: 114 presidential and 170 legislative. The number of more competitive elections in which no party received 50 percent of the vote is 137: 46 presidential and 91 legislative. Table A1 in the online appendix summarizes this information. We use Sambanis' (2004) coding of civil war initiation and the onset of minor conflicts identified in the UCDP/PRIO Armed Conflict Dataset (Gleditsch et al. 2002; Harbom and Wallensteen 2010).

Table 1 supports two important observations. First, across the entire post-WWII period, competitive multiparty elections in Africa, however defined, are associated with an increase in the frequency of minor civil conflicts. In the two years following elections in which no party obtained more than 50 percent of the vote, minor conflicts begin 5.49 percent of the time, whereas their relative frequency in other years is only 3.56 percent. This is consistent with the recent literature on elections and civil and social conflict. Second, the relationship between elections and conflict events depends on the type of conflict, the competitiveness of elections, and the historical period.

Over the entire post-WWII period, the relationship between competitive elections and civil war is weaker than the relationship between elections and minor conflicts. When we consider the most competitive elections (no party with more than 50 percent of the vote), the relative frequency of civil wars increases, but the difference is not statistically significant. Yet, the Cold War is an important turning point in the relationship between multiparty elections and civil conflict. Considering the same set of multiparty elections, we see that during the Cold War, there is a strong and statistically significant increase in the frequency of civil wars around competitive elections but a negative, albeit statistically insignificant, relationship after the end of the Cold War. If we expand the definition of competitive elections to include those in which no party wins more than 90 or 100 percent of the vote, the difference between the Cold War and post-Cold War eras becomes stark as the negative relationship between elections and war in the latter period becomes large and statistically significant.

The relationships in Table 1 raise several puzzles. First, why are multiparty elections associated with a higher frequency of civil war onset during the Cold War period and a lower 
frequency in the post-Cold War period? Second, why is the positive relationship between multiparty elections and civil violence stronger for minor conflicts than for civil wars? Finally, why is it that the pacifying effect of multiparty elections in the post-Cold War period increases as the degree of electoral competition decreases?

We develop an informational theory of endogenous elections to explain these puzzles. We argue that elections provide the opposition with information about the domestic political strength of leaders. When the opposition is relatively strong and willing to fight this information facilitates power sharing among elites. When opponents are relatively weak and unable to remove the leader by force elections deter opposition elites from waging war.

Elections make civil war less likely in the post-Cold War period because they are more informative about the likely outcome from fighting. During the Cold War, external support for dictators and (or) their opponents played an important role in determining who would prevail in armed conflicts, weakening the link between the internal political support of leaders and civil war outcomes. In the post-Cold War period, decisive foreign intervention in domestic conflicts is less likely, which implies the connection between multiparty elections and civil war outcomes will be stronger.

To the extent that multiparty elections facilitate power sharing and coopt elites from the strongest opposition groups, they make large-scale civil wars less likely. Multiparty elections do not decrease the likelihood of minor conflict (or spontaneous and disorganized social violence) because these events are harder for coopted opposition elites to control. Some factions of the opposition may be excluded from power sharing and initiate violence. Low-level military leaders within the opposition may disregard the orders of elites to refrain from fighting. Moreover, the competitive nature of the election may induce violent practices related to attempts to mobilize and/or sway voters.

The relationship between competitive elections and civil war onset is relatively weak and statistically insignificant when elections are most competitive because the incentives for leaders to hold elections and share power are strongest under the conditions that make these arrangements least likely to succeed, that is, when the opposition is strong enough to take power by force and willing to bear the costs of fighting. Non-democratic leaders always face the threat of removal by force; this threat is more likely to become a reality when these leaders are weak (e.g., owing to international pressure or a weak economy) or social conflicts are more intense. Knowing that they face a higher threat of removal by force, these leaders may call multiparty elections as a way to defuse that possibility. It is possible, therefore, that multiparty elections in weakly institutionalized authoritarian regimes are observed precisely when the leader already faces a significant threat of being removed by force; that is, they are held when a civil war is already a real possibility and elections are nothing but an attempt to avoid war.

In the next section, we develop our theory about the conditions under which elections deter the opposition from initiating violence, facilitate negotiated settlements, and avoid otherwise imminent civil wars. Before we proceed, however, we want to point out that our theory is consistent with several strands of recent work, all of which point to the role elections play in defusing conflict. According to Wantchekon and Neeman (2002), elections allow contenders in a civil conflict to lay down their weapons and fight peacefully for the power that they were not able to obtain in the battlefields. Other work has emphasized the relationship between the emergence of democracy (often understood as competitive elections and all that they entail) and the threat of violence. Thus, for Przeworski (Przeworski 1991; Przeworski 2005; Przeworski 2006), contestants in a competitive election will accept the results-choose not to pursue by force the outcome not obtained by vote-when the costs of fighting are so high that they exceed the costs of waiting for the next opportunity to win power peacefully, that is, of 
waiting for the next election. Acemoglu and Robinson (2005) suggest that democracy emerges when the threat of a revolution by the poor is sufficiently real to compel the rich to create institutions-democracy-under which a certain amount of income redistribution will be guaranteed. Londregan and Vindigni $(2006,3)$ argue that elections are a cheap and credible way to reveal information about the balance of forces in the battlefield. Their reasoning is that participation in elections is costly for individuals. Elections, thus, reveal the number of people who are willing to incur some costs to gain a trivial advantage for their side-they "provide a signal about the relative number of combatants each side could draw on in case of civil war." For this reason, election returns facilitate bargaining among factions because the information about their strength is available. Finally, Cox (2009), argues that authoritarian leaders agree to hold multiparty elections, in which they face some risk of losing power, in order to gain information that reduces the risk of their violent removal from office (via a coup or a revolution).

There are other arguments about why elections are held under authoritarian regimes and why they may have conflict-avoiding effects. Matanock (2012), for instance, argues that in post-conflict settings, elections serve as a commitment device in the difficult interaction between incumbent and combatants as they allow relatively easy monitoring and sanctioning of deviations from peace agreements by international organizations. Others see elections (and other democratic institutions) as a safety valve for releasing pressure against the authoritarian regime, which stems either from society (Gandhi 2008) or from the regime coalition (Svolik 2012). Finally, Magaloni (2006) argues that elections in authoritarian systems serve to bolster the regime's strength and deter opponents. These arguments too imply that elections may serve as a way to defuse an existing and simmering conflict.

Nonetheless, our theory is distinct in important ways. Most notably, we combine two mechanisms through which multiparty elections reduce the likelihood of civil war-deterrence and power sharing - in a original way and relate these mechanisms to the likelihood of outside intervention. Thus, our theory is able to account for the changes we observe regarding the relationship between elections and civil war in the post-Cold War world. Moreover, for our deterrence mechanism, only the margin of victory matters and not the degree of fraud or the overall quality of the election, and this distinguishes our argument from the vast majority of work on authoritarian elections.

\section{AN INFORMATIONAL THEORY OF ENDOGENOUS MULTIPARTY ELECTIONS}

In this section, we develop an information theory of endogenous elections under authoritarianism. We start with several core theoretical assumptions. First, and most importantly, we assume that dictators use multiparty elections to avoid costly fighting and prolong their survival. Second, political support for incumbent dictators determines the probability that they prevail in civil war. Initially, we divide political support into two kinds, external (foreign) and internal (domestic). We later subdivide internal support into two additional categories, true and manufactured support. Third, there is asymmetric uncertainty about the dictator's level of political support. The dictator is more informed and the opposition less so. Fourth, multiparty elections provide information to the opposition about the dictator's level of internal political support and potentially serve as a focal point for political negotiations about who will rule. This can facilitate power sharing when the opposition is strong and deter aggression when the opposition miscalculates its strength. In consolidated democracies, elections determine who rules. Under authoritarian regimes, either stable or transitioning, election outcomes may or may not be respected. In this sense, elections do not directly determine who rules, but they do provide a focal point around which actors' expectations converge. Fifth, civil wars occur when 
the incumbent dictator and opposition fail to reach a peaceful agreement about who will control the state. From these assumptions, it follows that civil wars begin when the opposition underestimates the probability that it will lose a civil war or the incumbent either reneges on a power-sharing agreement or cannot credibly commit to one. ${ }^{4}$

When the opposition is unaware of its relative weakness, the deterrent effect of multiparty elections will be large. The election returns will signal the strength of the incumbent regime and dissuade the opposition from initiating war. Under these conditions, that is, when the opposition is weak, we argue that it does not matter whether the incumbent's support is true or manufactured through electoral fraud. If the incumbent is able to use intimidation, bribery and its control of institutions, such as the press, to prevent the opposition from winning a meaningful share of the vote, the deterrent effect will be the same. Although the challenges of electoral competition under authoritarianism are formidable, an opposition that cannot win 10 percent of the vote has very little chance on the battlefield. ${ }^{5}$ When the opposition is strong, the deterrent effect of multiparty elections will be small. The election will confirm the opposition's beliefs that it can challenge the incumbent regime successfully, and if the election does not produce a settlement acceptable to both parties, and particularly if the incumbent "bargains" in bad faith by manipulating, nullifying, or ignoring the election outcome, the opposition may choose to initiate a war.

In this case, however, the election does not cause the war. The worst thing that the incumbent regime could do under these circumstances is refuse to hold an election at all, so that the only course of action for the opposition is to attempt to take power by force. On the other hand, if the incumbent respects the electoral process and uses the outcome as a basis for sharing power, war may be averted. The incumbent remains in power-even if now sharing it—and avoids an attempted takeover by force. ${ }^{6}$ The election does not guarantee peace, but it is the only hope for a peaceful accommodation of the conflict between the incumbent and the opposition.

\footnotetext{
${ }^{4}$ Our theory closely follows the logic of bargaining theories of war. For the classic statement, see Fearon (1995). The critical part of our argument is that multiparty elections are most informative about civil war outcomes when outside intervention is unlikely, and this information either deters weak opponents or helps to coopt strong ones. Other assumptions such as asymmetrical uncertainty only serve to simplify a formal representation of the theory from which our statistical model is derived.

${ }^{5}$ It is possible that other sources of information could correct miscalculations that lead to war. If there were easily substitutable alternatives, we would not observe a higher frequency of civil war in the absence of multiparty elections. For example, if miscalculating rebel groups will learn about their mistakes quickly from early battles, we might expect them to stop fighting before the conflict escalates and many lives are lost. We think that this scenario is unlikely because commitment problems make it difficult for both parties to end the violence once a conflict is initiated. To end the fighting, the rebels would have to commit to never again take up arms in return for the leader's pledge to not eliminate the opposition. However, any commitment made while the rebels are weak would not be credible if they ever became strong. Knowing this, once the war starts the leader has a strong incentive to fight until the opposition is destroyed.

6 One important concern with our power-sharing argument is that most scholars think of power sharing exclusively in terms of high profile accords, which are relatively rare in Africa. This view of power sharing, however, has been challenged recently by Francois, Rainer and Trebbi (2015) who argue power sharing in Africa frequently occurs through cabinet appointments. Their data show that ministerial posts are distributed across ethnic groups in a way that reflects their relative size. In an argument very similar to the one we are proposing, they posit that chief executives share power, in part, to avoid revolutions/civil wars, and one of the key parameters determining how widely power must be shared is the likelihood that the opposition can depose the leader by force. There is no uncertainty about this probability in their framework, but if there is uncertainty (as we assume) and electoral information helps to reduce it, then even winner-take-all elections can facilitate power sharing through the distribution of ministerial posts. Thus, power sharing can occur through formal, high profile arrangements such as the unity government agreements in Kenya and Zimbabwe; but it can also occur through less formal and newsworthy means such as the distribution of posts.
} 
Paradoxically, thus, the incentives for authoritarian regimes to hold multiparty elections are greatest precisely when they are least likely to prevent civil war, that is, when the opposition is strong and its ability to take power by force is credible. Therefore, we must be careful drawing causal inferences from a few prominent historical cases. The fact that we occasionally observe violence in the wake of multiparty elections does not tell us about the effect of electoral competition under more typical circumstances.

To make our theoretical framework more concrete, we start with a simple spatial model of crisis bargaining. Define $Z=[0,1]$ as an interval representing the possible range of settlements to a dispute between an incumbent dictator $(A)$ and an opposition $(B)$. We assume that the dispute is about who will rule. The dictator $(A)$ prefers to maintain complete control, the outcome at $z=1$, and would impose this outcome if victorious. The opposition $(B)$ also prefers complete control, $z=0$, and would behave similarly, imposing its most preferred outcome. We assume that the dictator receives utility $u_{A}(z)$, the opposition receives utility $u_{B}(1-z)$, and, without loss of generality, $u_{j}(1)=1$ and $u_{j}(0)=0$ for $j=[A, B]$. To capture the notion of asymmetrical information, we assume the dictator knows the true probability that the opposition will lose a civil war, $p$. Thus, the dictator's ex ante expected utility from civil war is $E\left(u_{A}(z)-\sigma_{A} c_{A}\right)=p(1)+p(1-p)(0)-\sigma_{A} c_{A}=p-\sigma_{A} c_{A}$, where $c_{A}$ is the dictator's cost of fighting and $\sigma_{A}$ the dictator's sensitivity to these costs. Likewise, the opposition's expected utility from civil war is $E\left(u_{B}(1-z)-\sigma_{B} c_{B}\right)=p_{B}(0)+\left(1-p_{B}\right)(1)-\sigma_{B} c_{B}=1-p_{B}-\sigma_{B} c_{B}$, where $p_{B}$ is the opposition's subjective probability that the dictator will win a civil war, $c_{B}$ the opposition's cost of fighting, and $\sigma_{B}$ the opposition's sensitivity to these costs. The costs of fighting, $c_{j}$, are strictly positive, and the sensitivity parameters, which capture the degree to which these costs are internalized by both actors, are assumed to fall within the interval $0 \leq \sigma_{j} \leq 1$. At one extreme, the actors are insensitive to the costs of conflict, and at the other, they fully internalize these costs. Assuming risk neutrality, both the dictator and the opposition will prefer a negotiated settlement in the range $\left(p-\sigma_{A} \mathrm{c}_{A}, p_{B}+\sigma_{B} \mathrm{c}_{B}\right)$ if it exists.

Civil war outcomes are determined by draws from a Bernoulli distribution with parameter $p$, which is known to the dictator. We assume that we can represent the opposition's uncertainty about $p, p \in P$ and $P=[0,1]$, using a probability distribution with support over the $[0,1]$ interval (e.g., a beta distribution). By the law of iterated expectations, $E\left(u_{B}(1-z)-\sigma_{B} c_{B}\right)=E\left[E\left(u_{B} \mid\right.\right.$ $\left.\left.p_{B}\right)-\sigma_{B} c_{B}\right]=1-\mathrm{E}\left(p_{B}\right)-\sigma_{B} c_{B}$, which says that the opposition's ex ante expected utility from civil war is equal to one minus the expected probability that the dictator wins less the internalized cost of fighting. ${ }^{7}$ With beliefs over the parameter $p$, the Pareto efficient bargaining range becomes $\left(p-\sigma_{A} c_{A}, E\left(p_{B}\right)+\sigma_{B} c_{B}\right)$. We argue that, under the right conditions, multiparty elections can provide information about $p$, the probability that the dictator will prevail in civil war, by signaling the level of internal support for the dictator. Multiparty elections can also provide a focal point for power-sharing negotiations. That said, vote shares should not be confused with the parameter $p$, even though they are on the same scale. The Pareto efficient bargaining range depends on $p$. If the opposition wins 10 percent of the vote share, this may translate into a probability of winning a civil war that is very close to 0 , which would imply no power sharing. In this case, the election outcome simply deters the opposition from initiating violence.

Figure 1 represents graphically the basic logic of this argument. Civil war can happen when both the incumbent dictator $(A)$ and the opposition $(B)$ prefer fighting to a negotiated settlement. Both sides may prefer to fight when the opposition underestimates the probability that it will

\footnotetext{
${ }^{7}$ We present civil wars as winner-takes-all contests, but the parameter $p$ could be described more generally as the expected outcome from fighting. In the case of winner-takes-all, the expected outcome is the probability of winning, but it could also represent the expected settlement after fighting to a stalemate.
} 


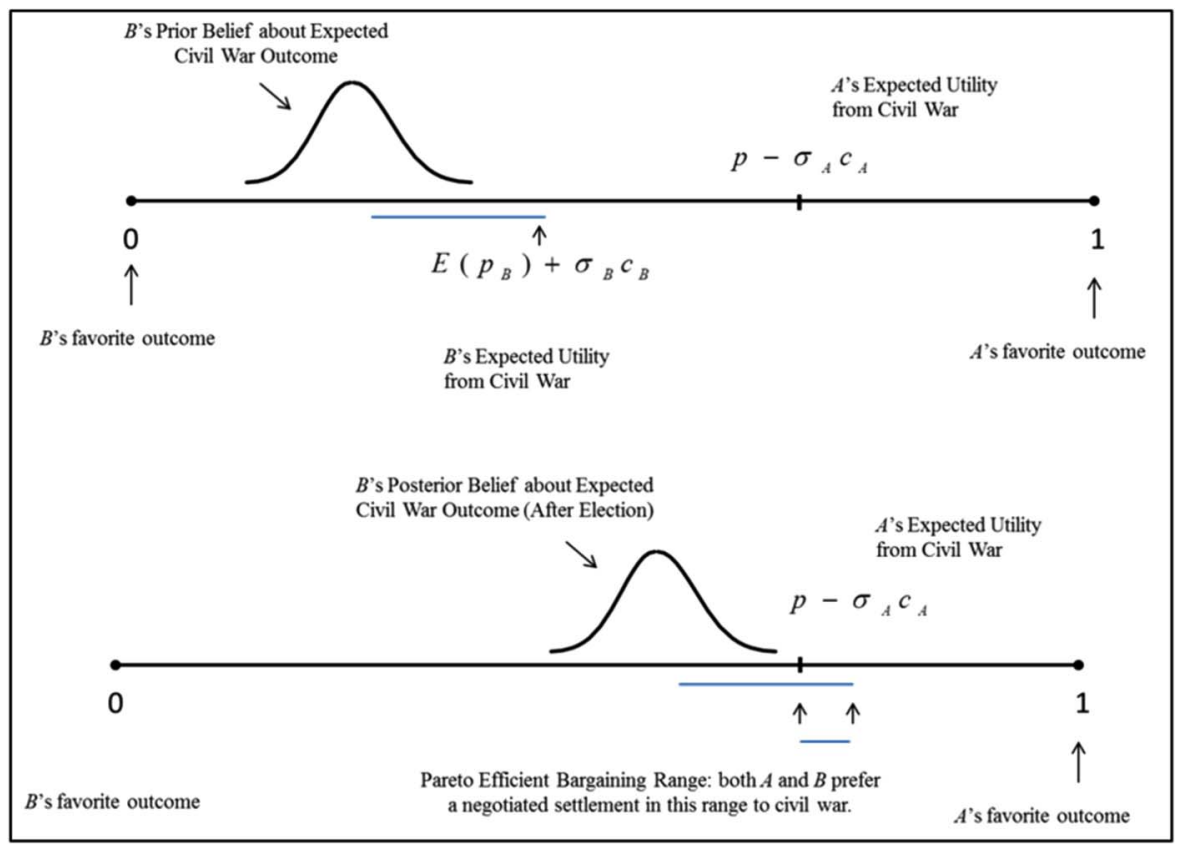

Fig. 1. Informative elections, bargaining, and civil war

lose, $p>E\left(p_{B}\right)$ and when the actors do not internalize the costs of fighting. The opposition's expected utility from civil war is represented in Figure 1 by the interior end point of the line segment under the $[0,1]$ interval. The dictator's expected utility is represented by the tick mark on the interval. The length of the line segment, which originates at the mean of $B$ 's belief distribution, corresponds to the internalized cost of war. Unless the line segment crosses the tick mark, assuming risk neutrality, there is no negotiated settlement that both sides prefer to fighting. In the top half of Figure 1, this is the case, and civil war is imminent.

If multiparty elections are to facilitate negotiated settlements and avoid otherwise imminent civil wars, they must cause the opposition beliefs to converge sufficiently to the true $p$. The bottom half of Figure 1 provides an example of sufficient post-election convergence. As the opposition's posterior beliefs have moved a distance such that the interior point of its internalized cost of fighting line segment has passed the tick mark, the election has created a Pareto efficient bargaining range. Both the incumbent dictator and the opposition prefer a negotiated settlement in this range to civil war. ${ }^{8}$ The degree to which the opposition's beliefs converge to the truth after an election depends on (1) the novelty of the information regarding domestic political support for the dictator provided by the polling and (2) the importance of domestic political support for civil war outcomes. We assume convergence results from Bayesian updating of prior beliefs about expected civil war outcomes using electoral information. Posterior beliefs are the product of likelihoods and priors. More specifically, the opposition estimates domestic political support for the dictator from the electoral data by assessing the

\footnotetext{
${ }^{8}$ This does not guarantee peace if the actors cannot credibly commit to these settlements. Moreover, the allocation of political power can be lumpy and discontinuous rather than smooth and continuous. It may be difficult to allocate power in a Pareto efficient way.
} 
likelihood of observing the realized election outcome for given (i.e., assumed) levels of support. They then update their prior beliefs about expected civil war outcomes. We provide an illustration of this learning in our online appendix.

Two stages connect multiparty elections and civil war under authoritarianism. In the first stage, the dictator decides whether to hold or allow an election. If there is an election, the opposition updates its beliefs about its prospects of winning a civil war and then, in a second stage, decides whether to initiate fighting. Thus, there are two correlated decisions in our framework. To show how these decisions are connected, we embed the spatial model of crisis bargaining within a bivariate random utility model.

The incumbent dictator will hold or allow a multiparty election when the utility of doing so is greater than the utility of not doing so. More formally, we assume $u_{1 A}^{*}=\mathbf{x}_{1} \boldsymbol{\beta}_{1}+\varepsilon_{1}$, where $u_{1 A}^{*}$ is the difference in utility received from holding an election and not holding an election, $\mathbf{x}_{1}$ a vector of fixed observable factors that influence the dictator's utility, $\boldsymbol{\beta}_{1}$ a vector of utility weights, and $\varepsilon_{1}$ a random unobservable component of the dictator's utility. We assume that $\varepsilon_{1}$ and therefore $u_{1 A}^{*}$ can take any value on the real number line, unlike the utilities from the simple spatial model, which are bound.

The opposition will initiate a civil war if the utility of doing so is greater than the utility from accepting a negotiated settlement. In order to put the utilities from the simple spatial model on the same scale as $u_{1 A}^{*}$, we define $\varepsilon_{2}=\Phi^{-1}\left(\sigma_{B}\right)$, where $\Phi^{-1}$ is an inverse distribution function with support over the real number line. It follows that the opposition's utility function is

$$
u_{2 B}^{*}=\Phi^{-1}\left[\left(E\left(p_{B}\right)-p+\sigma_{A} c_{A}\right) c_{B}^{-1}\right]+\varepsilon_{2} .
$$

We rule out the cases where the outcome is deterministic in the sense that the decision to initiate fighting does not depend on the opposition's sensitivity parameter, which implies $0<\left(E\left(p_{B}\right)-p+\sigma_{A} c_{A}\right) c_{B}^{-1}<1$. In this framework, the dictator's decision to hold an election is endogenous if $\operatorname{cov}\left(\varepsilon_{1}, \varepsilon_{2}\right) \neq 0$.

As the dictator, all else equal, would prefer to avoid a costly civil war, the decision to hold an election will reflect the dictator's beliefs about the opposition's sensitivity to the cost of fighting. If these beliefs are at least partially correlated with the truth, the dictator's willingness to hold an election will increase with the risk of civil war. Moreover, we argue that these beliefs are more important in determining $\varepsilon_{1}$, the dictator's random unobservable utility, when the opposition is strong. In other words, dictators derive more utility from holding elections in the face of civil wars that they might lose.
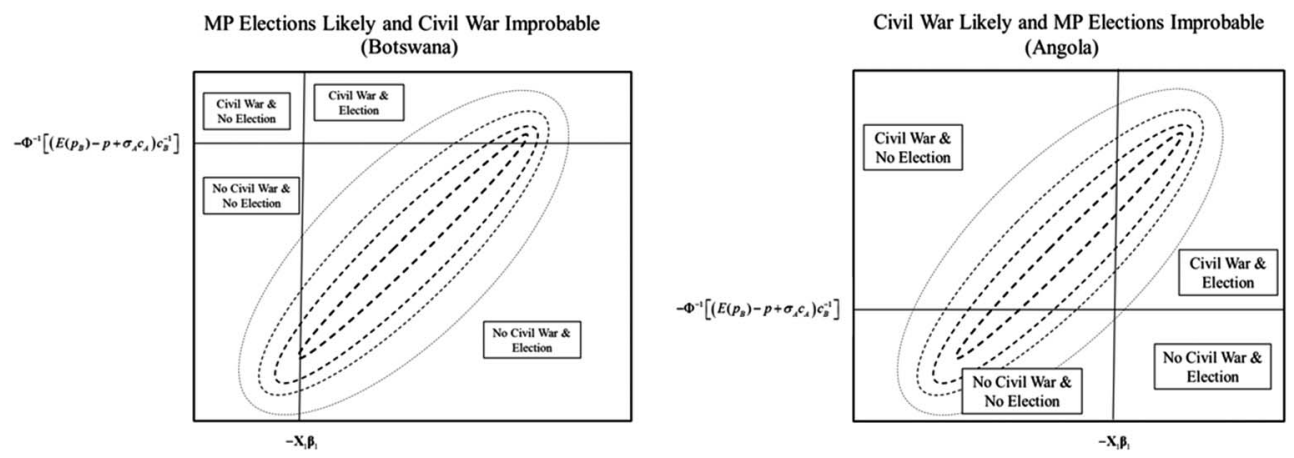

Fig. 2. Endogenous elections in two contexts 
Figure 2 shows graphically the connection between a dictator's decision to hold an election and an opposition's decision to initiate a civil war in two different contexts. The horizontal axes in this figure represent the dictator's decision to hold an election. If the random unobserved component of the dictator's utility, $\varepsilon_{1}$, is greater than $-\mathbf{x}_{1} \boldsymbol{\beta}_{1}$, the dictator will hold an election. The vertical axes represent the opposition's decision to initiate a civil war. If the random unobserved component of the opposition's utility, $\varepsilon_{2}$, is greater than $-\Phi^{-1}\left[\left(E\left(p_{B}\right)-p+\sigma_{A} c_{A}\right) c_{B}^{-1}\right]$, the opposition will choose to fight. The probability contour ellipses indicate which regions of the outcome space are more and less likely. Dark and thick contour ellipses identify regions that are more likely than light and thin ones. Given the way the contours are drawn, elections are endogenous, $\operatorname{cov}\left(\varepsilon_{1}, \varepsilon_{2}\right)>0$. Importantly, this figure shows how broadly applicable the endogenous elections framework is. All that is necessary for elections to be endogenous is that the random unobserved component of a dictator's utility from holding an election correlates (across countries and time) with the random unobserved component of an opposition's utility from fighting a civil war. This can be true in seemingly democratic countries like Botswana, where we observe frequent multiparty elections (but no turnover in leadership) and no civil war, as well as in countries like Angola, where we do observe civil war and multiparty elections are less frequent.

In the next section, we discuss the empirical implications of our theoretical model, stated as testable hypotheses.

\section{EMPIRICAL EXPECTATIONS ABOUT ELECTIONS AND CIVIL WAR}

In our Bayesian updating framework, if electoral outcomes reveal significant information about civil war outcomes, they could generate posterior distributions that differ significantly from prior beliefs. When will this be the case? We start with an explanation for the break in the nature of the elections-civil war relationship observed at the end of the Cold War.

Many factors affect civil war outcomes: the military competence of the opposing sides, their relative stock of munitions, the state of military technology, the nature of the battlefield terrain, etc. Some of these factors are known to the actors - perhaps technology and terrain — but others such as competence are not directly observed. In our theory, we highlight two of the most important determinants of civil war outcomes, both of which are unobserved: internal (domestic) and external (foreign) support for the incumbent dictator. If domestic support for the dictator is low, the opposition is more likely to, inter alia, recruit soldiers effectively, find safe haven among civilians, and more successfully solicit useful information from the general population about the incumbent regime. External support for the dictator (or opposition) can also be important. Foreign allies can supply weapons, finance, intelligence, training, and even soldiers. If the probability that the dictator prevails in civil war depends on variables that are unobserved, then beliefs about this probability will be some mixture of beliefs about its underlying unobservable components. We argue that the opposition's beliefs about the probability that a dictator will prevail in civil war are in part a mixture of its beliefs about internal and external support for the dictator.

Our theory provides a simple answer for why elections failed to deter civil war during the Cold War, but do now. During the Cold War, external support for dictators, particularly support from one of the two superpowers, was extremely important for determining whether these dictators could defeat significant domestic opposition in armed conflict. Both superpowers supported domestically unpopular dictators, weakening the link between internal political support and civil war outcomes. This is no longer true. In the post-Cold War period, decisive foreign intervention in domestic armed conflicts is less likely. Therefore, the connection 
between internal political support and civil war outcomes is stronger than during the Cold War, which implies that the connection between multiparty elections and civil war outcomes is stronger in the post-Cold War period as well. Thus, posterior distributions representing beliefs about expected civil war outcomes are more likely to converge in response to electoral information in the post-Cold War period. This implies that elections are more likely to create a Pareto efficient bargaining range with negotiated settlements that both the incumbent dictator and the opposition prefer to civil war. ${ }^{9}$ To put it explicitly, multiparty elections reduce the risk of civil war in the post-Cold War period, but not during the Cold War.

When an opposition believes that it can win a civil war and is willing to bear its costs, the incumbent can survive in one of several ways. The dictator can win a costly conflict, deter the opposition by changing its beliefs about its chances of victory, or offer the opposition a settlement on terms that both sides find acceptable. To the extent that multiparty elections signal the regime's strength or make Pareto efficient agreements possible, incumbent dictators will allow them to occur when conflict is imminent in order to avoid the costs of war. In other words, elections are endogenous to the probability of civil war. To be clear, when a country is on the brink of civil war, dictatorial regimes benefit from holding multiparty elections. Elections may deter a weak opposition from launching a costly war that the dictator will ultimately win but still prefers not to fight. In this case, dictators allow multiparty elections to reveal information about the true risk of war for the opposition. In turn, when the opposition is strong, elections may fail to prevent a civil war; but they may also provide the basis for power-sharing arrangements, in which case dictators maintain some control over the state and avoid civil wars that they could possibly lose. Thus, we should expect that during the post-Cold War period, authoritarian regimes are more likely to hold multiparty elections when the risk of civil war is high.

We expect all multiparty elections under authoritarianism to be both endogenous to the risk of civil war and to have some pacifying effect. In other words, the likelihood that an organized opposition will try to take power by force will always figure to some extent into a dictator's calculation about whether to hold multiparty elections or not. That said, our theory generates more precise conclusions about the nature of this endogeneity and its implications for peace. The random utility a dictator receives from holding elections, $\varepsilon_{1}$ in our theoretical model, depends on many things. Some of these factors are context specific (e.g., it may be more difficult and financially costly to plan and hold elections in some countries than others); others depend on the dictator (there are likely reputational or psychological costs to the holding of elections); and others yet depend upon characteristics of the opposition, most importantly, its strength. Dictators hold multiparty elections to avoid costly civil wars, and fighting always entails costs; but the ultimate cost is being removed from power, which can only happen when the opposition is strong.

Thus, a dictator's beliefs about the willingness of the opposition to bear the costs of war, which we assume correlates with the truth $\left(\varepsilon_{2}\right)$, will largely determine $\varepsilon_{1}$ when the opposition is strong and play a far less significant role when the opposition is weak. In other words, the incentives for authoritarian regimes to hold multiparty elections are greatest, precisely when they are least likely to prevent civil war, that is, when the opposition is strong and its ability to take power by force is credible. In these cases, elections have less of a deterrent effect. Election outcomes may serve as a focal point for political negotiations over the distribution of power, but these agreements are

\footnotetext{
${ }^{9}$ See the online appendix for a formal illustration of this proposition. Francois, Rainer and Trebbi (2015) argue that African leaders are more likely to share power in the post-Cold War period because of declining levels of intervention. They note, citing Hentz (2004), that US aid was cut to less than half of its peak level of \$2.4 billion in 1985 during the post-Cold War period. The decline in Russian aid has been even more significant.
} 
difficult to craft and sustain. As a consequence, a civil war may ensue. Thus, even though the election may be followed by a civil war, the election per se did not cause it. In turn, when the opposition is weak, the risk of civil war is driven by miscalculation. Elections correct the opposition's mistaken beliefs and deter conflict: there is no need for real power sharing. Thus, it follows that the degree to which elections are endogenous to the risk of civil war is higher when the opposition is strong. However, at the same time, the pacifying effect of elections is smaller when the opposition is strong.

These hypotheses state the most important empirical implications of our theoretical model. We evaluate them in the next section. Before we proceed, we point out that our theoretical framework is compatible with analyses that view the introduction of multiparty elections in Africa in the early 1990s as the result of a crisis of legitimacy of incumbent regimes and the increased assertiveness of opposition forces (Bratton and van de Walle 1997; Moss 2011). An incomplete list of countries where such elections were held includes Cameron in 1992, Cape Verde in 1991, the Central African Republic in 1998, Chad in 1996, Ethiopia in 1995, Gabon in 1990, Guinea in 1992, Kenya in 1992, Malawi in 1994, Mali in 1992, Namibia in 1994, Niger in 1993, Togo in 1994, and Zambia in 1991. Although a few of these countries transitioned to democracy, most of them remained under an authoritarian regime after elections revealed a relatively weak opposition (either because it did not have true support from the population or because the regime was able to "produce" a result that favored it). Significantly, none experienced civil war (although a few experienced minor civil conflicts), at least not at any point that could be directly traced to the occurrence of the election. Alternatively, many cases of post-election civil war initiation involved a strong opposition (as indicated by the regime's inability to garner true or manufacture sufficient support), failed attempts to negotiate some kind of power-sharing agreement, or simply the regime's unwillingness to accept the election's results. No case exemplifies this better, we believe, than the Algerian election of 1991, the regime's refusal to accept the outcome, and the country's descent into civil war in 1992.

\section{ESTIMATED EFFECTS OF ENDOGENOUS MULTIPARTY ELECTIONS ON CIVIL} WAR INITIATION

Our empirical strategy is simple. We take what we consider to be the best empirical models of civil war onset and authoritarian multipartyism from the literature and estimate them simultaneously. We start with a single-equation model of civil war onset. Our dependent variable comes from Sambanis (2004), who defines civil war as an armed conflict between the government and an organized insurgent group that results in at least 500 deaths, with 100 deaths inflicted on the stronger party. ${ }^{10}$ To evaluate the effects of multiparty elections on civil war onset under varying levels of opposition strength, we estimate three probit models in which we distinguish the nature of multipartyism by degrees of electoral competitiveness. For the first definition, we identify any election where no single party earned 100 percent of the vote share. This is the minimal, all-inclusive definition of a multiparty election. For the second definition, we count only those elections where no single party earned 90 percent of the vote. By this definition, we exclude elections where the opposition is vanishingly small, but many of these elections remain non-competitive. In the final definition, we include only competitive multiparty elections, those in which no party wins a majority of the vote share. These are the cases in

\footnotetext{
${ }^{10}$ According to Sambanis, "the start year of the war is the first year that the conflict causes at least 500 to 1,000 deaths. If the conflict has not caused 500 deaths or more in the first year, the war is coded as having started in that year only if cumulative deaths in the next 3 years reach 1,000" (2004, 829-30). The original data covers the 1946-2002 period. Nicholas Sambanis graciously shared the update to 2005.
} 
which the opposition is relatively strong. According to our theory, in this last set of cases, we expect the incentives to hold elections as well as their effects to be somewhat distinct from those cases where the opposition is weak. We allow elections to have effects for up to two years after the polling. ${ }^{11}$ Following the classical studies of Fearon and Laitin (2003) and Sambanis (2004), we include per capita income, GDP growth, oil exports, ethnic heterogeneity, population, the proportion of mountainous terrain, percent of Muslims in the population, and whether there was a war in the previous year as the principal determinants of civil war onset. ${ }^{12}$

Our first set of estimates, which we report in Table 2, looks very similar to the results in Sambanis. Like Sambanis, we find that GDP per capita and oil exporter status are statistically significant predictors of civil war onset. An increase in per capita income decreases the likelihood of onset, whereas being an oil exporter increases it. The only difference between our results and his is that population is not statistically significant in the post-Cold War African sample. In terms of fit, Sambanis reports a pseudo $R^{2}$ of 0.072 for his model, which is comparable with our range of 0.072-0.101. Based on these comparisons with Sambanis, we are satisfied that we have a good model for civil war onset, to which we add our multiparty election dummy variables.

Two things are important about our results. First, we continue to find that multiparty elections are associated with a decrease in the likelihood of civil war onset. Notably, the association that we highlighted in the second section does not disappear when we control for the most important observable determinants of civil war onset. The estimated average effect is a 0.04 reduction (from 0.059 to 0.019 ) in the probability of civil war onset when using the first all-inclusive definition and a 0.034 reduction (from 0.054 to 0.020 ) when we use the 90 percent vote-share threshold to define multiparty elections. This provides some preliminary evidence that multiparty elections, as we expected, reduce the risk of civil war in the post-Cold War period. Second, if we focus exclusively on competitive multiparty elections (no party with a majority of votes), the effect is no longer statistically significant. This is consistent with our expectation that the deterrent effect of multiparty elections is smaller when the opposition is relatively strong. At the same time, we expect the decision to hold multiparty elections when the opposition is strong to be endogenous to the likelihood of civil war onset. The incumbent will hold elections when the opposition is strong, willing, and ready to fight. Thus, it is problematic to generalize from these cases to less ignitable contexts.

To address our endogeneity concern, we estimate a set of recursive bivariate probit models (Maddala 1983; Greene 2008). With three assumptions, this econometric model follows directly from our theoretical framework. First, we assume that the inverse function, $\Phi^{-1}$, is for a standard normal distribution. This implies, among other things, that the opposition's transformed sensitivity term or its willingness to fight, $\varepsilon_{2}=\Phi^{-1}\left(\sigma_{B}\right)$, is distributed as a standard normal. Second, we assume that the covariates in Table 2 operate through the causal mechanisms outlined in our theoretical model by affecting the objective and subjective probabilities of victory, as well as the costs of fighting and sensitivity to these costs. In other words, we assume that we can substitute $\mathbf{x}_{2} \boldsymbol{\beta}_{2}$ for $\Phi^{-1}\left[\left(E\left(p_{B}\right)-p+\sigma_{A} c_{A}\right) c_{B}^{-1}\right]$ in the equation for $u_{2 B}^{*}$ and estimate a reduced-form version of the structural model:

$$
u_{2 B}^{*}=\mathbf{x}_{2} \boldsymbol{\beta}_{2}+\varepsilon_{2} \text {. }
$$

\footnotetext{
${ }^{11}$ More specifically, our multiparty election indicator variables take a value of one in the election year and in the two years after. There are three instances of civil war onset during election years, but in all three cases the wars follow the elections.

12 By focusing on Africa, we control for extreme heterogeneity in political institutional context by design. For this reason, we do not include the instability and anocracy dummy variables in Sambanis (2004), although our results are robust to their inclusion. Sambanis analyzes a global sample with significant political institutional diversity. We do account for some intra-continental heterogeneity in our models of multiparty elections.
} 
TABLE 2 Probit Models of Civil War Onset with Exogenous Elections, Africa, 1990-2005

\begin{tabular}{lccc}
\hline & & Multiparty & \\
\cline { 2 - 4 } Variable & $100 \%$ & $90 \%$ & $50 \%$ \\
\hline GDP & $-0.325(0.098)^{* * *}$ & $-0.332(0.106)^{* * *}$ & $-0.347(0.104)^{* * *}$ \\
GDP growth & $-1.46(1.54)$ & $-1.40(1.54)$ & $-1.09(1.51)$ \\
Oil exporter & $0.743(0.254)^{* * *}$ & $0.751(0.251)^{* * *}$ & $0.759(0.257)^{* * *}$ \\
Ethnic fractionalization & $0.377(0.603)$ & $0.382(0.610)$ & $0.314(0.619)$ \\
Population & $-0.653(0.453)$ & $-0.623(0.457)$ & $-0.633(0.487)$ \\
Terrain & $0.005(0.006)$ & $0.005(0.006)$ & $0.006(0.006)$ \\
Percentage Muslim & $-0.000(0.002)$ & $-0.000(0.002)$ & $-0.000(0.002)$ \\
War at $(t-1)$ & $-0.199(0.208)$ & $-0.171(0.206)$ & $-0.100(0.208)$ \\
Multiparty election & $-0.566(0.193)^{* * *}$ & $-0.478(0.190)^{* * *}$ & $-0.225(0.211)$ \\
Average effect & $-0.042(0.014)^{* * *}$ & $-0.035(0.013)^{* *}$ & $-0.017(0.014)$ \\
Observations & 723 & 723 & 723 \\
Log likelihood & -109.36 & -110.66 & -112.97 \\
Pseudo $R^{2}$ & 0.101 & 0.091 & 0.072 \\
\hline
\end{tabular}

Notes: parentheses contain cluster-corrected (by country) standard errors. ***, **, * significant at $0.01,0.05,0.10$ levels, respectively.

Third, we assume the incumbent's unobserved utility from holding an election is a function of $\varepsilon_{2}$. More specifically, we assume $\varepsilon_{1}=\rho \varepsilon_{2}+\sqrt{1-\rho^{2}} \eta_{1}$, where $\eta_{1}$, a component of the incumbent's unobserved random utility that is unrelated to the opposition's willingness to fight, is also distributed as a standard normal. These assumptions produce the following recursive bivariate probit model:

$$
\begin{aligned}
& u_{1 A}^{*}=\mathbf{x}_{1} \boldsymbol{\beta}_{1}+\varepsilon_{1}, \text { where } u_{1 A}=1 \text { if } u_{1 A}^{*}>0,0 \text { otherwise, } \\
& u_{2 A}^{*}=\mathbf{x}_{2} \boldsymbol{\beta}_{2}+\gamma u_{1 A}^{*}+\varepsilon_{2}, \text { where } u_{2 A}=1 \text { if } u_{2 A}^{*}>0,0 \text { otherwise, } \\
& E\left[\varepsilon_{1} \mid \mathbf{x}_{1}, \mathbf{x}_{2}\right]=E\left[\varepsilon_{2} \mid \mathbf{x}_{1}, \mathbf{x}_{2}\right]=0, \\
& \operatorname{var}\left[\varepsilon_{1} \mid \mathbf{x}_{1}, \mathbf{x}_{2}\right]=\operatorname{var}\left[\varepsilon_{2} \mid \mathbf{x}_{1}, \mathbf{x}_{2}\right]=1 \\
& \operatorname{cov}\left[\varepsilon_{1}, \varepsilon_{2} \mid \mathbf{x}_{1}, \mathbf{x}_{2}, u_{1 A}\right]=\rho
\end{aligned}
$$

Importantly, the degree to which the decision to hold an election is endogenous to the opposition's willingness to fight, the size of $\rho$, will depend on the strength of the opposition. If the opposition is strong enough to remove the incumbent from power by force, the opposition's willingness to fight will largely drive the decision to hold an election. If the opposition is weak, the decision to hold an election will be driven by other concerns, $\eta_{1}{ }^{13}$

To complete the recursive bivariate probit model, we need a model of the incumbent's decision to hold multiparty elections. For this, we turn to Gandhi's work on political institutions under authoritarianism (Gandhi and Przeworski 2007; Gandhi 2008). In her framework, dictators accede to multipartyism for three primary reasons. First, they allow multipartyism when their need for societal cooperation is high. This depends largely on the nature of authoritarianism. There are ready-made institutions to help organize rule under monarchy and military regimes - the royal family or court and the armed forces, respectively - that reduce the

\footnotetext{
${ }^{13} \mathrm{Or}$, if we assume the incumbent does not know $\varepsilon_{1}$, then $\eta_{1}$ may contain some random noise in the incumbent's belief.
} 
need for societal cooperation. There is no equivalent under civilian dictatorships. In addition, the need for societal cooperation is a function of the dependence of the ruler on society for revenue. Regimes that can tap natural resources for state revenue need less cooperation. Second, policy polarization reduces the likelihood that the ruler will accept multipartyism. Finally, the strength of the opposition determines the likelihood of multipartyism. This is precisely our argument for the endogeneity of multiparty elections. When the opposition is strong and willing to use force to topple the regime, dictators are more likely to hold multiparty elections. To capture these three sources of pressure on dictators to allow multiparty elections, we follow Gandhi's lead as much as possible. We include indicator variables for the type of authoritarianism (and in a few cases, a democracy indicator), the oil exporter variable, ethnic fractionalization as a proxy for policy polarization, the number of inherited parties, the amount of past executive turnover, and the percentage of other countries that are democratic. To Gandhi's list of covariates, we add the number of previous multiparty elections, using the all-inclusive definition (i.e., any election where two or more parties won vote shares). Countries that have had many multiparty elections in the past are more likely to have them in the future (Lindberg 2009). ${ }^{14}$

We report our results in the bottom half of Table 3. Our findings differ in several ways from Gandhi's, so it is worthwhile to understand the differences in our respective analyses. First, we have a different dependent variable. In the study by Gandhi and Przeworski (2007), the dependent variable is the number of legislative parties and in the study by Gandhi (2008), it is a set of ordered categories that describe increasing levels of institutionalization under dictatorship. The highest category is for dictatorships with multiparty legislatures. Multiparty elections are the instrument that produces multiparty legislatures, so the two explananda are strongly related. Clearly, theory that explains why dictators allow multiparty legislatures also explains why dictators allow the multiparty elections that lead to multiparty legislatures. Nevertheless, differences in dependent variables require different econometric models, and this partly accounts for the differences in our empirical results. Second, and probably most importantly, we have different samples. Gandhi's samples are for all dictators over the entire post-WWII period, whereas our sample is for all of Africa over the post-Cold War period. (Our results are robust to limiting estimation to the non-democratic subsample (see below).) Third, we have added to our analysis independent variables that were not present in Gandhi's work. Most significantly, we include the number of previous multiparty elections, which is a powerful predictor of future multiparty elections, and a democracy indicator. The latter is justified by the fact that our sample includes all of Africa, and approximately 19 percent of the country-years are coded as democratic. Finally, we report robust standard errors clustered by countries.

\footnotetext{
${ }^{14}$ Our results are robust regardless of the definition we use to construct this variable. The previous elections variable also addresses the issue of whether first multiparty elections are unique when compared with elections that are held more as a matter of routine. Countries that have held multiparty elections in the past are very likely to hold them in the future, although elections are not guaranteed to continue indefinitely. First elections are much rarer events, but they do occur with positive probability. Again, we stress that our theoretical and empirical models are able to accommodate this degree of heterogeneity, the difference between Botswana and Angola, for example (see Figure 2). The previous elections variable shifts the election cut-point sufficiently to account for both low and high probability elections.

It is worth noting that the selection equations in our recursive bivariate probits are models of institutionalization and address the possibility that multiparty elections might correlate with institutional capacity, which in turn determines the likelihood of civil war. This is done through the disturbances across the civil war and multiparty election equations. If we observe an election in a place where we do not expect to see one, it is almost certainly in a low capacity environment (e.g., Angola). Our analysis suggests that these "unexpected elections," are more likely to occur in countries on the brink of civil war.
} 
TABle 3 Recursive Bivariate Probit Models of Civil War Onset with Endogenous Multiparty Elections, Africa, 1990-2005

\begin{tabular}{|c|c|c|c|}
\hline \multirow[b]{2}{*}{ Variable } & \multicolumn{3}{|c|}{ Multiparty } \\
\hline & $100 \%$ & $90 \%$ & $50 \%$ \\
\hline GDP & $-0.308(0.099)^{* * *}$ & $-0.304(0.098)^{* * *}$ & $-0.298(0.097)^{* * *}$ \\
\hline GDP growth & $-1.13(1.52)$ & $-0.968(1.52)$ & $-0.621(1.43)$ \\
\hline Oil exporter & $0.688(0.240) * * *$ & $0.711(0.227)^{* * *}$ & $0.776(0.242) * * *$ \\
\hline Ethnic fractionalization & $0.405(0.580)$ & $0.498(0.566)$ & $0.385(0.573)$ \\
\hline Population & $-0.518(0.445)$ & $-0.457(0.436)$ & $-0.375(0.439)$ \\
\hline Terrain & $0.004(0.005)$ & $0.003(0.005)$ & $0.003(0.005)$ \\
\hline Percentage Muslim & $-0.000(0.002)$ & $-0.000(0.002)$ & $-0.000(0.002)$ \\
\hline War at $(t-1)$ & $-0.194(0.189)$ & $-0.169(0.180)$ & $-0.102(0.173)$ \\
\hline Multiparty election & $-1.07(0.321)^{* * *}$ & $-1.12(0.329)^{* * *}$ & $-1.13(0.320)^{* * *}$ \\
\hline Average effect & $\begin{array}{l}-0.078[-0.151 \\
-0.033]^{* * *}\end{array}$ & $\begin{array}{c}-0.074[-0.159 \\
-0.034] * * *\end{array}$ & $\begin{array}{l}-0.036[-0.095 \\
-0.018]^{* * *}\end{array}$ \\
\hline Military & $0.509(0.348)$ & $0.079(0.347)$ & $-0.699(0.491)$ \\
\hline Civilian & $0.516(0.371)$ & $0.184(0.363)$ & $-0.403(0.477)$ \\
\hline Democracy & $1.01(0.380)^{* *}$ & $0.727(0.394) *$ & $0.057(0.520)$ \\
\hline Oil exporter & $-0.019(0.224)$ & $0.135(0.217)$ & $0.475(0.277)$ \\
\hline Ethnic fractionalization & $0.066(0.041)$ & $0.665(0.320)^{* *}$ & $0.584(0.395)$ \\
\hline Inherited parties & $0.051(0.106)$ & $0.055(0.116)$ & $0.176(0.112)$ \\
\hline Leadership changes & $-0.065(0.041)$ & $-0.036(0.041)$ & $-0.063(0.037) *$ \\
\hline Other democracies & $4.99(2.18)^{* * *}$ & $4.94(2.13)^{* * *}$ & $6.24(2.73)^{* *}$ \\
\hline Number of previous MP elections & $0.168(0.033) * * *$ & $0.154(0.035) * * *$ & $0.056(0.035)$ \\
\hline Correlation coefficient $(\rho)$ & $0.395[-0.010,0.689]^{*}$ & $0.496[0.046,0.779]^{* *}$ & $0.665[0.084,0.909]^{* *}$ \\
\hline \multicolumn{4}{|l|}{ Linear probability model } \\
\hline First-stage $F$-statistic & $22.32 * * *$ & $19.86 * * *$ & $14.69 * * *$ \\
\hline Sargan test & 7.35 & 6.42 & 7.76 \\
\hline Observations & 723 & 723 & 723 \\
\hline Log likelihood & -534.77 & -532.25 & -473.98 \\
\hline
\end{tabular}

Notes: parentheses contain cluster-corrected (by country) standard errors, and brackets contain 95 percent confidence intervals. ***, **, * significant at $0.01,0.05,0.10$ levels, respectively.

In the models where we include non-competitive elections in our definition of multiparty elections (i.e., the all-inclusive and 90 percent threshold operationalizations), the democracy indicator, other democracies, and number of previous MP election variables provide most of the explanatory power. In the model where we only include competitive elections, leadership changes and the other democracies variables are the most important predictors. Overall, we are satisfied with the explanatory power of our model. Our predictive accuracy ranges from 58.5 percent for competitive multiparty elections to 68.5 percent for all multiparty elections. This is comparable with the predictive accuracy range of 53.4-65.7 percent reported in the study by Gandhi (2008).

Our primary reason for estimating the endogenous elections model is to account for unobservable determinants of these elections that might also affect the likelihood of civil war. Theoretically, we expect the incumbent's beliefs about the willingness of the opposition to fight, particularly when the opposition is strong, to be extremely important in determining the choice to hold multiparty elections, and these beliefs are unobservable. In terms of the empirical model, we are mostly interested in the coefficient on our multiparty election dummy variable, the covariance parameter, $\rho$, and the causal effects they imply. Formally, this model is identified by its structural assumptions, but semiparametric identification and precise estimation require 
strong and excludable instruments. The literatures on civil war onset and authoritarian institutions are largely separate. With the exceptions of natural resource abundance and ethnic fractionalization there is no overlap in terms of the set of explanatory variables. For example, variables such as the type of authoritarianism, which are theorized to determine the degree of institutionalization under dictatorship, have not been theorized to have a direct effect on civil war onset. In this sense, we have seven instruments (non-overlapping variables) in our model of multiparty elections.

We are interested in the extent to which these variables are strong and excludable. To evaluate the quality of our instruments, we also estimate a system of linear probability models using 2SLS. First-stage $F$-statistics are frequently used to assess the strength of instruments. With a single endogenous variable, an $F$-statistic of 10 or larger is usually considered a reliable indicator that the instrument set is strong. Our first-stage $F$-statistics, reported at the bottom of Table 3, exceed ten in all three models. The Sargan test evaluates whether the instruments are excludable by examining their ability to predict the model's second-stage residuals. The null hypothesis is that the model is overidentified. If the instruments have no predictive power for the second-stage residuals, their effect on civil war onset is indirect only through the endogenous variable, and the model is overidentified. We fail to reject the null hypothesis for all three models. Thus, the evidence suggests our instruments are both strong and excludable. This is not necessary for identification, but it greatly increases our confidence in the estimates, which we report in the top half of Table 3.

With the exception of our multiparty election coefficients, the results do not change much from the single-equation estimates provided in Table 2. The election coefficients and effect estimates are much larger, however, and this is because we find strong evidence that the decision to hold multiparty elections is endogenous: our estimates for the correlation between the two error terms, $\rho$, are positive and statistically significant across all three models. In short, we underestimate the pacifying effect of elections in the single-equation models because historically we observe elections in those cases where they are most likely to fail. This provides strong support for the first two hypotheses in the fourth section.

The estimated average effect of multiparty elections is a 0.078 reduction in the probability of civil war onset when using the all-inclusive definition of multiparty elections and a 0.074 reduction when we use 90 percent vote-share threshold. In contrast with our Table 3 estimate, we now find that competitive multiparty elections reduce the probability of civil war onset by 0.036. The pacifying effect remains smaller, however, which is consistent with our theoretical expectations. We also see that the degree of endogeneity, the size of the correlation in disturbances across the two equations, grows as we narrow our focus on competitive elections. For our all-inclusive, 90 percent threshold, and competitive election variables, the estimated correlations are approximately $0.40,0.50$, and 0.67 , respectively. These results provide support for our expectation that multiparty elections are more likely to happen, but their pacifying effects are weaker, when the opposition is strong.

In Table 4, we check the robustness of our result in several ways, reporting both the multiparty election and correlation coefficient estimates. First, we control for potential pacifying effects of multidimensional peacekeeping forces during elections. In several of the elections in our sample, there were peacekeeping forces on the ground. The extant literature shows that peacekeeping forces, particularly those missions with election monitoring, increase the durability of peace (Fortna 2008). When we control for peacekeeping, the main election result still remains: multiparty elections reduce the likelihood of civil war in the post-Cold War period in Africa. Second, many of the peace settlements ending civil wars in the post-Cold War era call for both power sharing and elections. If power sharing explains peace (and this is one of the mechanisms that we highlight in our theory) and these peace agreements mandate both power 
TABLE 4 Bivariate Probit Extensions and Robustness Checks

\begin{tabular}{|c|c|c|c|}
\hline \multirow[b]{2}{*}{ Variable/Parameter } & \multicolumn{3}{|c|}{ Multiparty } \\
\hline & $100 \%$ & $90 \%$ & $50 \%$ \\
\hline \multicolumn{4}{|l|}{ Multidimensional peacekeeping } \\
\hline Multiparty election & $-1.09(0.323)^{* * *}$ & $-1.14(0.334)^{* * *}$ & $-1.15(0.320)^{* * *}$ \\
\hline Correlation coefficient $(\rho)$ & $0.402[-0.001,0.692]^{*}$ & $0.505[0.054,0.785]^{* *}$ & $0.678[0.104,0.913]^{* *}$ \\
\hline \multicolumn{4}{|l|}{ Power-sharing arrangements } \\
\hline Multiparty election & $-1.07(0.338) * * *$ & $-1.14(0.345)^{* * *}$ & $-1.15(0.404) * * *$ \\
\hline Correlation coefficient $(\rho)$ & $0.371[-0.076,0.694]$ & $0.486[-0.009,0.790]^{*}$ & $0.661[0.031,0.915]^{* *}$ \\
\hline \multicolumn{4}{|l|}{ Previous wars } \\
\hline Multiparty election & $-1.05(0.323)^{* * *}$ & $-1.10(0.332)^{* * *}$ & $-1.09(0.334)^{* * *}$ \\
\hline Correlation coefficient $(\rho)$ & $0.340[-0.020,0.688]^{*}$ & $0.487[0.028,0.777] * *$ & $0.644[0.028,0.906]^{* *}$ \\
\hline \multicolumn{4}{|l|}{ African non-democracies } \\
\hline Multiparty election & $-1.02(0.363)^{* * *}$ & $-1.12(0.386)^{* * *}$ & $-1.13(0.436) * * *$ \\
\hline Correlation coefficient $(\rho)$ & $0.333[-0.139,0.682]$ & $0.485[-0.048,0.803]^{*}$ & $0.617[-0.173,0.924]$ \\
\hline \multicolumn{4}{|l|}{ Global non-democracies } \\
\hline Multiparty election & $-1.12(0.332)^{* * *}$ & $-1.31(0.355)^{* * *}$ & $-1.25(0.359) * * *$ \\
\hline Correlation coefficient $(\rho)$ & $0.548[0.113,0.807]^{* *}$ & $0.729[0.176,0.932]^{* *}$ & $0.741[-0.273,0.975]$ \\
\hline \multicolumn{4}{|l|}{ PRIO } \\
\hline Multiparty election & $-1.01(0.558)^{*}$ & $-1.03(0.547)^{*}$ & $-1.30(0.492)^{* * *}$ \\
\hline Correlation coefficient $(\rho)$ & $0.287[-0.394,0.764]$ & $0.356[-0.329,0.796]$ & $0.712[-0.258,0.967]$ \\
\hline
\end{tabular}

Notes: parentheses contain cluster-corrected (by country) standard errors, and brackets contain 95 percent confidence intervals. $* * *, * *, *$ significant at $0.01,0.05,0.10$ levels, respectively.

sharing and elections, the relationship between elections and peace could be spurious. We identify all of the peace settlements requiring both power sharing and elections using Högbladh's (2012) Peace Agreement data set and include these agreements as a variable in our analysis. The results suggest that these agreements do reduce the likelihood of civil war recurrence, but their inclusion does not change our results for elections. Third, we also control for the number of previous civil wars. This variable should identify countries that are at high risk of civil war and have low levels of institutionalization as conflict erodes institutional capacity. Including the number of previous civil wars does not change our results. ${ }^{15}$ Fourth, we check to make sure our results are robust when we estimate the model with the non-democratic subsample of African countries. We believe that our theoretical argument applies to all of the African regimes, including the cases of unconsolidated democracy, but our basic empirical results do not change. When we estimate the model using only non-democracies, our estimates, including our estimates for the correlation coefficients, are nearly identical, which suggests we are justified in pooling the African cases. Focusing on the non-democratic subsample does reduce our sample size by nearly 20 percent, which increases the size of our standard errors. Fifth, we also estimated the model using a global sample of non-democracies, and again, our results are largely robust. Multiparty elections reduce the likelihood of civil war onset. The

\footnotetext{
${ }^{15}$ We also included the anocracy and instability variables used by Sambanis to capture variation in institutional capacity and another measure of institutionalization - the proportion of years a country has lived under leaders who have completed their constitutionally specified terms-created on the basis of Przeworski et al. (2013). In addition, we performed the analysis including controls that may further reduce the variation in institutional capacity, such as the share of foreign aid or of tax revenue in a country's gross national income and the accumulated number of changes in the head of government. All of the results we report about the impact of multiparty elections on the probability of civil war initiation remain unchanged. We do not report these results, but they can be obtained from the authors by request.
} 
correlation coefficient $(\rho)$ for the model with competitive multiparty elections is estimated imprecisely, but this is not surprising given that the global sample introduces more heterogeneity in unobservables. Finally, we check whether the pacifying effects of elections in postCold war period hold when we use the PRIO definition of high-intensity civil wars. The results indicate that this is indeed the case, although our correlation coefficient estimates are less precise.

Thus, the evidence strongly supports the notion that multiparty elections in weakly institutionalized contexts reduce the risk of civil war onset. Leaders in these countries allow them to happen when conditions are such that the risk of civil war is already high. When the opposition is weak, elections provide information about the regime's strength and deter the opposition from fighting a war that it is likely to lose. When the opposition is strong, elections may lead to a negotiated settlement in the form of some kind of power-sharing agreement. These agreements are fragile and difficult to sustain. They may fall apart and a civil war may erupt, but in this case the elections did not cause it. In either case, multiparty elections expand the range of possible peaceful behavior on the part of both incumbent leaders and opposition, thus reducing the likelihood that a civil war will be initiated.

\section{CONCLUSION}

A large body of literature has developed suggesting that holding multiparty elections in weakly institutionalized transitional regimes may have perverse consequences: rather than ushering in an era of prosperity and democracy, by forcing political actors unsure about their ability to compete for the popular vote, these elections instead generate instability and civil conflict. The brutal and destructive civil wars that erupted after the collapse of the Soviet Union and the end of the Cold War almost certainly informed those who came to espouse this view, serving as the basis for generalizing to what has become accepted as an obvious and almost inevitable relationship between electoral pressures and civil conflict. An increasing number of voices were heard criticizing attempts by the United States, the European Union, and international organizations such as the World Bank to use diplomacy to push for multiparty elections or to impose political conditionality on countries receiving foreign aid.

This paper offers evidence that challenges this view. Even though some very salient conflicts might have erupted following attempts to hold multiparty elections in transitioning countries, the conclusion that there is a causal relationship between the two events may not be warranted. If anything, the data for Africa during the post-Cold War period suggest the opposite: the timing of multiparty elections, even in weakly institutionalized political regimes, is associated with a lower frequency of large-scale civil war onset. This is true no matter how one looks at the data.

In order to account for this pattern, we developed an informational theory of elections held under conditions that prevail in the post-Cold War world, one in which foreign powers are reluctant to provide direct support for dictators (or their opponents) and elections are more reflective of the true level of a leader's strength. We argue that, under these conditions, elections may prevent the eruption of a civil war that is already imminent, through two mechanisms: they may deter a weak opposition from initiating a war they are likely to lose, or they may induce a weak dictator to offer ways to share power with the opposition. Our theory also sheds light on the prominent post-Cold War cases in which multiparty elections and civil war onset coincide. According to it, non-democratic leaders will have the strongest incentive to hold multiparty elections precisely when they are least likely to prevent a civil war, that is, when the opposition is strong and its ability to take power by force is credible. Thus, even though the election may be followed by a civil war, the election per se did not cause it. 
In conclusion, democracy proponents may have less reason to worry about holding multiparty elections, even during the early stages of regime change, than is commonly believed. At worst, these elections may prolong temporarily the rule of some autocrats and possibly generate low levels of civil violence (Salehyan and Linebarger 2015). On the positive side, multiparty elections reduce the likelihood of large-scale civil conflict and may hasten the transition to democracy (e.g., Schedler 2002; Howard and Roessler 2006; Lindberg 2009; Donno 2013).

\section{REFERENCES}

Acemoglu, Daron, and James Robinson. 2005. Economic Origins of Dictatorship and Democracy. Cambridge: Cambridge University Press.

Brancati, Dawn, and Jack L. Snyder. 2013. 'Time to Kill: The Impact of Election Timing on Postconflict Stability'. Journal of Conflict Resolution 57(5):822-53.

Bratton, Michael, and Nicolas van de Walle. 1997. Democratic Experiments in Africa: Regime Transitions in Comparative Perspective. Cambridge: Cambridge University Press.

Cederman, Lars-Erik, Kristian Skrede Gleditsch, and Simon Hug. 2012. 'Elections and Ethnic Civil Wars'. Comparative Political Studies 46(3):387-417.

Cederman, Lars-Erik, Simon Hug, and Lutz F. Krebs. 2010. 'Democratization and Civil War: Empirical Evidence'. Journal of Peace Research 47(4):377-94.

Chua, Amy. 2003. World On Fire: How Exporting Free Market Democracy Breeds Ethnic Hatred and Global Instability. New York, NY: Random House.

Collier, Paul. 2009. Wars, Guns, and Votes. New York, NY: HarperCollins Publishers.

Cox, Gary W. 2009. 'Authoritarian Elections and Leadership Succession, 1975-2000'. University of California, San Diego, CA. Typescript.

Donno, Daniela. 2013. 'Elections and Democratization in Authoritarian Regimes'. American Journal of Political Science 57(3):703-16.

Fearon, James. 1995. 'Rationalist Explanations for War'. International Organization 49(3):379-414.

Fearon, James, and David Laitin. 2003. 'Ethnicity, Insurgency, and Civil War'. American Political Science Review 97(1):75-90.

Flores, Thomas Edward, and Irfan Nooruddin. 2012. 'The Effect of Elections on Postconflict Peace and Reconstruction'. Journal of Politics 74(2):558-70.

Fortna, Virginia Page. 2008. Does Peacekeeping Work? Shaping Belligerents' Choices After Civil War. Princeton, NJ: Princeton University Press.

Francois, Patrick, Ilia Rainer, and Francesco Trebbi. 2014. 'How Is Power Shared in Africa?', Econometrica 83(2):465-503.

Gandhi, Jennifer. 2008. Political Institutions Under Dictatorship. Cambridge: Cambridge University Press.

Gandhi, Jennifer, and Adam Przeworski. 2007. 'Authoritarian Institutions and the Survival of Autocrats'. Comparative Political Studies 40:1279-301.

Gleditsch, Nils Petter, Peter Wallensteen, Mikael Eriksson, Margareta Sollenberg, and Håvard Strand. 2002. 'Armed Conflict 1946-2001: A New Dataset'. Journal of Peace Research 39(5): $615-37$.

Greene, William H. 2008. Econometric Analysis 7th ed. New York, NY: Prentice Hall.

Harbom, Lotta, and Peter Wallensteen. 2010. 'Armed Conflict, 1946-2009'. Journal of Peace Research 47(4):501-09.

Hegre, Håvard, Tanja Ellingsen, Scott Gates, and Nils Petter Gleditsch. 2001. 'Toward a Democratic Civil Peace? Democracy, Political Change, and Civil War, 1816-1992'. American Political Science Review 95(1):33-48.

Hentz, James. 2004. 'The Contending Currents in United States Involvement in Sub-Saharan Africa'. In Ian Taylor and Paul Williams (eds), Africa in International Politics: External Involvement on the Continent, 23-40. Uppsala, London: Routledge. 
Högbladh, Stina. 2012. 'Peace Agreement Dataset Codebook, Version 2.0'. Uppsala Conflict Data Program, Department of Peace and Conflict Research, Uppsala University.

Howard, Marc, and Phillip Roessler. 2006. 'Liberalizing Electoral Outcomes in Competitive Authoritarian Regimes'. American Journal of Political Science 50(2):365-81.

Huntington, Samuel P. 1968. Political Order in Changing Societies. New Haven, CT: Yale University Press.

Hyde, Susan D. 2011. The Pseudo-Democrat's Dilemma: Why Election Observation Became an International Norm. Ithaca, NY: Cornell University Press.

Kuenzi, Michelle, and Gina Lambright. 2001. 'Party System Institutionalization in 30 African Countries'. Party Politics 7(4):437-68.

Lindberg, Staffan I. 2009. 'The Power of Elections in Africa Revisited'. In Staffan Lindberg (ed.), Democratization by Elections: A New Mode of Transition. 25-46. Baltimore, MD: Johns Hopkins University Press.

Londregan, John, and Andrea Vindigni. 2006. 'Voting as a Credible Threat'. Fondazione Collegio Carlo Alberto, Carlo Alberto Notebooks, No.18, Torino, Italy.

Maddala, Gangadharrao Soundalyarao. 1983. Limited-Dependent and Qualitative Variables in Econometrics. Cambridge: Cambridge University Press.

Magaloni, Beatriz. 2006. Voting for Autocracy: Hegemonic Party Survival and its Demise in Mexico. Cambridge: Cambridge University Press.

Matanock, Aila M. 2012. 'Bullets for Ballots: Examining the Effect of Electoral Participation on Conflict Recurrence'. Paper presented at the Annual Meeting of the Midwest Political Science Association. Chicago, IL, 12-15 April.

Moss, Todd J. 2011. African Development: Making Sense of the Issues and Actors 2nd ed.. Boulder, CO: Lynne Rienner.

Ndulo, Muna. 2007. 'The Judiciary, Constitutionalism and Human Rights'. Democratization in Africa: What Progress Toward Institutionalization? Ghana Center for Democratic Development, National Intelligence Council. Washington, DC, 4-6 October, pp. 81-92.

Posner, Daniel N., and Daniel J. Young. 2007. 'The Institutionalization of Political Power in Africa'. Journal of Democracy 18(3):126-40.

Przeworski, Adam. 1991. Democracy and the Market; Political and Economic Reforms in Eastern Europe and Latin America. New York, NY: Cambridge University Press.

Przeworski, Adam. 2005. 'Democracy as an Equilibrium'. Public Choice 123:253-73.

Przeworski, Adam, Tamar Asadurian, Anjali Thomas Bohlken, Carolina Curvale, and Sunny Kuniyathu. 2006. 'Self-Enforcing Democracy'. In Donald Wittman and Barry Weingast (eds), Oxford Handbook of Political Economy, 312-28. New York, NY: Oxford University Press.

Przeworski, Adam et al. 2013. 'Political Institutions and Political Events (PIPE) Dataset'. Department of Politics, New York University.

Salehyan, Idean, and Christopher Linebarger. 2015. 'Elections and Social Conflict in Africa, 1990-2009'. Studies in Comparative International Development 50(1):23-49.

Sambanis, Nicholas. 2004. 'What is Civil War?: Conceptual and Empirical Regularities of an Operational Definition'. Journal of Conflict Resolution 48(6):814-58.

Schedler, Adreas. 2002. 'The Menu of Manipulation'. Journal of Democracy 13(2):36-50.

Snyder, Jack. 2000. From Voting to Violence: Democratization and Nationalist Conflict. New York, NY: Norton.

Snyder, Jack, and Edward Mansfield. 2012. 'Democratization and Civil War'. In Jack Snyder (ed.), Power and Progress: International Politics in Transition, 175-200. New York, NY: Routledge.

Svolik, Milan. 2012. The Politics of Authoritarian Rule. Cambridge: Cambridge University Press.

Wantchekon, Leonard, and Zvika Neeman. 2002. 'A Theory of Post-Civil War Democratization'. Journal of Theoretical Politics 4(14):439-64.

Zakaria, Fareed. 1997. 'The Rise of Illiberal Democracy'. Foreign Affairs 76(6):22-43. 